\title{
ACCOUNTING STUDENTS' PERCEPTIONS: INTERNAL CONTROL THEORY MOVES OUTSIDE THE CLASSROOM AND ONLINE
}

\author{
N. D. Sexton \\ School of Accountancy \\ Stellenbosch University \\ Stellenbosch, South Africa \\ e-mail: nsexton@sun.ac.za
}

\section{ABSTRACT}

Many have argued that faculty should transform the way accounting programmes are presented to undergraduate students. Changes in student expectations, professional qualifications and employer demands have driven innovative experiential learning interventions. Students want to learn collaboratively, inside and outside of the classroom, they want to use information technology and have fun. In response, this article reports on an auditing assignment where students were required to identify control weaknesses in everyday life, record it and report back using Facebook. A Facebook group was created where students posted photos or videos of the control weakness they identified. Other students could "like," comment and share posts. This was the first assignment of this nature. This research presents the accounting students' perceptions of the assignment as a whole, the pervasive skills applied and the use of Facebook. These were generally positive and should encourage educators to keep integrating technology and real life into learning.

Key words: accounting education, auditing, social media, Facebook, pervasive skills.

\section{INTRODUCTION}

The training of chartered accountants in South Africa include tertiary education, professional examinations and practical training to achieve a core set of competencies as set out in the Competency Framework of the South African Institute of Chartered Accountants (SAICA 2010). The introduction of a competency-based model in line with international trends marked a significant shift in the manner in which prospective chartered accountants are trained from a primarily technical approach to one that reflects the increased need for pervasive (soft) skills in accounting practice (Keevy 2016, 459).

The path to chartered accountancy generally entails an undergraduate degree, a postgraduate certificate in the theory of accounting, and a traineeship of three years at a SAICAregistered training office while writing two professional examinations within that time. During this timeframe, in order to register as a chartered accountant in South Africa, all of the competencies within the Competency Framework should be attained. Communication between 
tertiary educators and training offices is critical to ensure that students who have completed their tertiary studies are prepared for and meet the requirements of training officers. To facilitate this, research has been conducted into what the perceptions of training officers are with respect to the preparedness and challenges those students who become trainee accountants' face. Training officers indicated that new trainee accountants find it challenging to translate their acquired academic knowledge into professional accountancy practice (De Villiers 2010, 2; Coetzee and Oberholzer 2009, 435; Barac 2009, 20). Training officers place emphasis on the fact that new trainees require certain pervasive or soft skills such as analytical, teamwork and communication skills when they commence their traineeship (Barac 2009, 29-30; Crawford, Helliar and Monk 2011, 117). The changing broader business and technological landscape has increased the importance of new trainees possessing basic information technology (IT) skills with extensive exposure to Microsoft Excel, Microsoft Word, email and the internet (Barac 2009, 35-36). These changes in the competency requirements of new trainee accountants are challenging educators to adopt differing pedagogical approaches to allow students to apply technical skills to practical scenarios, while working on their IT and pervasive skills (Barac 2009, 38).

\section{LITERATURE REVIEW}

\section{Factors that impact the pedagogies when teaching accounting students}

Tertiary education, as a key element of the training of a chartered accountant, is directly impacted by the requirements set out in the Competency Framework and the training officers' requirements. It is also impacted by the student sitting in class and the world in which they have grown up. Learning approaches should be designed in such a way that they both engage the student and achieve learning outcomes. This will support students to engage in a deep rather than surface learning approach. When engaging in deep learning students are encouraged not to merely learn to reproduce what they have learned and pass assessments (surface learning) but rather to learn with the intention understanding the material. They will further be given the opportunity to create relationships with existing knowledge structures and ultimately transfer the learning to different situations (deep learning) (Dolmans et al. 2016) (Hall, Ramsay and Raven 2004, 491). Students currently in the learning process fall within Generation Y or they are millennials (persons born between 1982 and about 2000) and Generation Z or IGen students (persons born after 2000) (Jones, Jo and Martin 2007, 887-888). Therefore, it is necessary to consider the backgrounds and learning preferences of both Generation $\mathrm{Y}$ and $\mathrm{Z}$ typologies. Both Generation $\mathrm{Y}$ and Generation $\mathrm{Z}$ students are the most technologically savvy students to ever be 
at university and they have differing learning preferences to their counterparts before them (Cilliers 2017, 191; Jones et al. 2007, 888; Wessels and Steenkamp 2009, 1040). Wessels and Steenkamp $(2009,1040)$ suggest that within the specific context of accounting education, the learning preferences of Generation $\mathrm{Y}$ that should be considered include the appropriate use of technology, teamwork, structure, experiential learning, real-life simulations and image-rich material. They further challenge faculty to apply enhanced pedagogical strategies to enable the modern student to learn in a manner that aligns with their learning styles and preferences (Wessels and Steenkamp 2009, 1049). Generation Y students wish to use technology as part of their learning interventions, but on their own terms and in a manner that suits their preferences (Wessels and Steenkamp 2009, 1054-1055). In general, Cilliers (2017, 193) suggests that Generation $\mathrm{Z}$ students have several similar learning preferences to those of Generation $\mathrm{Y}$ with an increased emphasis on the preference for online, electronic learning material, more contact sessions and fewer assignments. Notably, Generation $\mathrm{Z}$ students, who are the first generation to be born into the connected world, almost expect the use of social media and connectivity to be the norm (Rothman 2016). Blended learning in accounting education (face-to-face and technology) is now more than ever being used as a pedagogical approach. This has allowed students to be more connected, ask questions and get feedback from their lecturers and fellow students (Hiralaal 2012, 323). It is suggested that the use of social media tools enable the integration of IT into curricula through the use of tools that allow social networking (Menzies, Petrie and Zarb 2017, 51; Steenkamp and Rudman 2013, 369). The use of social media tools such as Facebook can facilitate collaborative learning by allowing students to work in groups (teamwork) (De Villiers 2015, 491; Wessels and Steenkamp 2009, 1043).

\section{Experiential learning as a response}

Educators have responded to these factors with innovative solutions to engage and enable students to achieve the required competencies. Auditing is one of the four professional subjects to be mastered by the accounting student. Several authors (Rudman and Terblanche 2011, 64; Steenkamp and Von Wielligh 2011, 9; Helliar, Monk and Stevenson 2009, 186; Arens, May and Donminiak 1970, 573) agree that auditing is often challenging for students to grasp as they have had little or no exposure to the business world or the business processes used in financial reporting. To breach this gap, educators have over time and as far as is practicable created experiential learning interventions with realistic business environments that can be applied to large classes within the time and other resources available (Rudman and Terblanche 2011, 64; Steenkamp and Von Wielligh 2011, 14; Arens et al. 1970, 574). Kolb (1984) provides the pedagogical support for experiential learning that considers the need for an individual to 
navigate the learning cycle of experiencing, reflecting, thinking and acting to concretise and support deep learning (Hall et al. 2004, 490). More recently, the NMC Horizon Report: 2017 Higher Education highlighted movements in higher education towards fostering authentic learning in projects and competency-based learning where students actively engage with the content (Adams Becker et al. 2017, 8). Experiential learning calls for students to actively engage with the subject matter and not merely observe, as has often been the case in the traditional lecture which, although it has a place in teaching, is often overused (Prince 2004, 225). This is achieved by allowing students to use theoretical frameworks and principles learned in real world scenarios, allowing them to master a skill (Wessels and Steenkamp 2009, 1053). This encourages active learning where students perform activities that require them to engage with the learning material to improve retention and performance (Prince 2004, 227). To engage students in experiential learning and to breach the gap between theory and real life, several auditing educators have used case studies, video simulations and technology-based simulations based on real-life business scenarios (De Villiers 2015, 485; Wessels and Steenkamp 2009, 1053; Steenkamp and Rudman 2007, 29). Student perceptions of these interventions have been studied and in general student perceptions are that these interventions enhance learning and provide an opportunity to practice technical and pervasive skill competencies (Steenkamp and Von Wielligh 2011, 10; Rudman and Terblanche 2011, 68; Steenkamp and Rudman 2007, 35; Stainbank 2005, 134).

\section{Blended learning and Facebook as a response}

Tertiary education trends have recently moved towards blended learning where traditional teaching and learning environments are enhanced by using face to face student interaction together with the strategic incorporation of education technologies as a tool to support students in achieving learning outcomes (Adams Becker et al. 2017, 2, Krause 2007 as cited in Bath and Bourke 2010,1). Accounting educators have embraced blended learning by creating learning interventions that intentionally include blended learning techniques to enable students to learn in line with their preferences whilst encouraging deeper learning (Hiralaal 2012, 317; Steenkamp and Rudman 2007, 29). Students' perceptions of these interventions have been positive and confirm Wessels and Steenkamp's $(2009,1049)$ notion that this generation of students want blended learning as a key part of their learning process on their terms. The most recent trend in higher education is to move blended learning onto more mobile platforms where learning becomes mobile and learning experiences are facilitated anytime, anywhere (Gezgin, Adnan and Acar Guvendir 2018, 4). Mobile learning can be based on institution-specific devices and software or it can be supported by means of social media platforms (Gezgin et al. 
$2018,4)$. One such social media platform that is widely used as a mobile as well as desktop application is Facebook (De Villiers 2015, 495). As students are already using the Facebook platform for social reasons and are familiar with the functionality of the application, they support its use in learning interventions (Menzies et al. 2017, 40; Bosch 2009, 193). Facebook also affords students mobile access with low data use and gives them the satisfaction of immediate interactive feedback. Presently, Facebook is used as a real-time formal or informal communication tool outside of the classroom among students themselves. Facebook is also used as a real-time communication tool between faculty and students when students are performing a simulation outside of class and they require clarity on areas of the work or administrative information (Menzies et al. 2017, 48; Petrović, Petrović and Jeremić 2012, 357; Bosch 2009, 195). The use of Facebook within learning interventions has been found to allow students to participate and collaborate, no matter the class size. It has encouraged critical thinking when discussions take place outside of classroom walls (Menzies et al. 2017, 41; Petrović et al. 2012, 357). These highlighted benefits of using Facebook can create opportunities to support students in deep learning when intentionally planned as part of learning activities. If students are required to engage in learning activities outside of the classroom in new unstructured environments, they are immediately able to question their understanding of the content and reference peers, previous experiences and knowledge structures with real time feedback. This encourages students to understand content and transfer principles learnt to new situations rather than repeat what they have learnt. However, one negative consideration that $\operatorname{Bosch}(2009,196)$ found in the use of Facebook for higher education is that it can blur the lines between private and professional activities. The lecturers decided to use Facebook as the as the platform for the \#auditsexy assignment as:

- It is widely used by the students who are already active on the platform,

- $\quad$ Signing up is free which meant little investment for the students or faculty,

- Some students already use it as a tool at university,

- It provides mobile access with a low data usage,

- Students are able to generate their own content, which aligns to their learning preferences and supports deeper learning,

- It allows for immediate interactive feedback,

- Students are familiar with the functionality in Facebook that was required to complete the assignment, and

- Faculty as well as students were willing to use their personal profiles on Facebook to support the assignment. 


\section{THE \#AUDITSEXY RESPONSE}

The undergraduate auditing lecturers of a SAICA-accredited university considered the nature of their current student cohort, the professional requirements and the evolution in pedagogical approaches to create a specific learning intervention - the \#auditsexy assignment. The objective was to allow students to take the theory of internal controls out of the classroom into the unstructured real world and to apply a connective report-back mechanism by running the assignment on Facebook. Students were tasked with working in small groups to create a video or photo of weaknesses in internal control identified in any context (industry, business, size of organisation) outside of the classroom. In 2015, to improve the learning, the corrective action was also required. The key learning outcome was to concretise general theoretical auditing knowledge on risk exposure and elements of internal control within any real-life environment to make it more practical. The assignment was intentionally not in the form of a case study or roleplay and placed very few creative or technical restrictions on the students. This was to try a different learning intervention to structured case studies and roleplays identified in the literature review. Students were required to load their assignments onto a Facebook group. In 2014, submissions were loaded onto an open Facebook group for fellow students and educators to like, review and respond to or comment on. However, untoward practices in 2014 from students who could post on the group without review and outside parties who requested access to or could see the content of the group presented unexpected risks. In 2015, a closed Facebook group was created, which provided lectures with more control. Each post and member had to be reviewed/moderated by lecturers before it could be released. To add an element of fun, the assignment was launched with an interactive video and discussion session. In a similar manner to a television game show, it was linked to sponsored prizes for the best video and photo (identifying valid weaknesses that had an impact on the financial statements) and several other categories, such as creativity, most likes and innovation. Prizes were handed out at an awards ceremony at the end of the assignment. Throughout the assignment, lecturers monitored the Facebook group, maintained an updated a leader board of likes and engaged students with Facebook pictures, videos and comment posts. To increase students' awareness of the social media risks associated with the use of Facebook, an expert in social media gave an hour-long presentation within the first week of the assignment. The assignment coincided with the lecturing of ethics in the curriculum. In an effort to integrate auditing topics, the ethical considerations of the students' submissions were discussed in class. As the assignment ran over a few weeks, this was done by a weekly \#auditsexy minute to discuss the reputational, ethical, business and personal risks of social media that presented themselves on the Facebook group 
over the preceding week. The video and photo submissions were used to revise principles of internal control.

\section{RESEARCH METHODOLOGY}

\section{Research objective, questions and contributions}

The purpose of this research was to test and analyse accounting student perceptions of the learning related to risks and internal control in the \#auditsexy assignment, their use of pervasive skills, the use of Facebook and their awareness of the personal impact of social media risks. These perceptions can then be used as considerations for future learning interventions. The following research questions arise from the literature review and the \#auditsexy response:

1. Did students find the unstructured \#auditsexy assignment outside of the classroom an effective tool to enhance their understanding of risks and internal control in any environment?

2. Did the \#auditsexy assignment create an opportunity for the student to practice and refine specific pervasive skills required by the profession?

3. What were the accounting students' perceptions of using Facebook as the platform for the \#auditsexy assignment and did it have an impact on their learning experience?

4. What additional knowledge and awareness did the students gain regarding the risks of social media to themselves, the university or to the businesses used in their Facebook posts?

The main contribution of this research is its examination of the students' perceptions of an unstructured assignment related to risk and internal controls outside of the classroom in any environment, not in the form of a business and industry-specific case study or roleplay as has been done in the past. Further, it considers if unstructured learning interventions are perceived to allow accounting students to practice the required pervasive skills. Finally, this research adds to the research on students' perceptions of the use of Facebook as a platform or tool for learning interventions in that it focusses specifically on accounting students and not on the general student population as has been done before. This allows accounting educators to consider if similar interventions in future would aid the exposure to the required competencies.

\section{Research design and data collection}

The researcher's goal was to use student perceptions to inform future learning interventions. 
The research thus fits within the paradigm of action research to assess whether or not the assignment achieved the intended outcomes and if future informed action should be taken to achieve the desired outcomes (Hiralaal 2012, 321; Fletcher 2015, 66). The research is empirical in nature.

In line with previous studies on student perceptions, questionnaires were used as the means to collect primary data (Steenkamp and Von Wielligh 2011, 13, Rudman and Terblanche 2011, 68; Kruger 2011, 41; Hiralaal 2012, 321). Questionnaires were designed based on literature regarding advances in accounting education, the Competency Framework and the use of Facebook at tertiary institutions. Questions surrounding social media risks and the impact on students were based on issues raised during the execution of the assignment. The study was focussed on the 2014 and 2015 second-year auditing cohorts. The final perceptions of these students were assessed against literature and considerations were identified for future learning interventions.

The questionnaire included a range of questions in four broad categories. First those relating to the structure, outcomes and execution of the assignment as a whole; second relating to the pervasive skills applied; third to knowledge of the risks of social media and finally relating to the use of Facebook. The questionnaire included several closed-ended questions using several response mechanisms, including a Likert scale, a "yes" or "no" option, a ranking and "select the most appropriate response". Open-ended comment questions where included in the questionnaire where individualised feedback was considered more appropriate. The questionnaire was emailed to all of the students in both cohorts. Participation in the study was voluntary and institutional ethical clearance and permission were obtained.

\section{Data analysis}

The data from the two surveys were transferred onto an Excel spreadsheet and then into the STATISTICA statistics programme. Data from questions with "agree" or "disagree" responses were tallied per year and the total responses in agreement included in the findings tables per statement or question. Statements where data were captured with the responses of 1, 2, 3, 4, 5 in the form of a Likert scale with 1 (not at all) and 5 (definitely), were collated. The data from 2014 and 2015 were combined and a mean and standard deviations were calculated. As the data were in the form of a Likert scale and thus ordinal, it may not necessarily be normally distributed. Thereafter, Pearson Chi-square tests were performed between the two years to identify significant variations between years. All differences that were significant and where $p$ $<0.05$ were discussed.

Written responses to open-ended questions were collated in Excel and analysed; where 
recurring themes presented themselves they were included in the appropriate research finding.

\section{FINDINGS}

The response rate to the questionnaire in 2014 was $41(7 \%)$ of the 580 students, which was found to be lacking. In 2015, $153(21 \%)$ of the 727 students responded, which represented a greater portion of the population. An analysis of the feedback obtained from the students is set out per research question.

\section{Did students find the unstructured \#auditsexy assignment outside of the classroom an effective tool to enhance their understanding of risks and internal control in any environment?}

\section{Overview of the assignment as a whole}

The statements in Table 1 tested the students' perceptions of the assignment as a whole, whether it was beneficial and if it should be used in future learning interventions. Approximately two thirds of the students in both cohorts perceived that they learned something new from the assignment. However, the majority of the students' perceptions were that the assignment allowed them to not only think more broadly about auditing, but also to think more practically and differently about auditing. As auditing is a practical subject that students often struggle to conceptualise, this achieved a key learning outcome of the assignment. This is consistent with the results that Steenkamp and Rudman $(2007,35)$ and Steenkamp and Von Wielligh (2011, 15-16) found when they used case studies to make auditing more practical. Students recommended that the assignment be used in future.

Students' general comments on the assignment as a whole were positive in that it allowed them to learn and they enjoyed participating in the assignment. The main negative comment was that students felt that they underestimated the amount of time they required to do the assignment and with other assessments in-between, they were under pressure.

Table 1: Perceptions of the \#auditsexy assignment as a whole

Questions in the form of Yes (agree) or No (disagree).

\begin{tabular}{|c|c|c|c|c|}
\hline \multirow{2}{*}{\multicolumn{2}{|c|}{ Question }} & \multicolumn{2}{|c|}{$\begin{array}{c}\text { Percentage of students who } \\
\text { agreed }\end{array}$} & \multirow{2}{*}{$\begin{array}{l}\text { Pearson Chi- } \\
\text { square between } \\
2014 \text { and } 2015\end{array}$} \\
\hline & & 2014 & 2015 & \\
\hline 1.1 & $\begin{array}{l}\text { Did you learn something new from the } \\
\text { assignment? }\end{array}$ & $66 \%$ & $66 \%$ & $\mathrm{P}=0.985$ \\
\hline 1.2 & $\begin{array}{l}\text { Did the assignment allow you to think more } \\
\text { broadly about auditing? }\end{array}$ & $90 \%$ & $95 \%$ & $P=0.203$ \\
\hline 1.3 & $\begin{array}{l}\text { Did the assignment allow you to think more } \\
\text { practically about auditing? }\end{array}$ & $93 \%$ & $96 \%$ & $\mathrm{P}=0.359$ \\
\hline 1.4 & $\begin{array}{l}\text { Did the assignment allow you to think differently } \\
\text { about auditing? }\end{array}$ & $83 \%$ & $87 \%$ & $P=0.511$ \\
\hline
\end{tabular}




\begin{tabular}{|c|c|c|c|c|}
\hline \multirow{2}{*}{\multicolumn{2}{|c|}{ Question }} & \multicolumn{2}{|c|}{$\begin{array}{c}\text { Percentage of students who } \\
\text { agreed }\end{array}$} & \multirow{2}{*}{$\begin{array}{c}\text { Pearson Chi- } \\
\text { square between } \\
2014 \text { and } 2015\end{array}$} \\
\hline & & 2014 & 2015 & \\
\hline 1.5 & $\begin{array}{l}\text { Would you recommend the assignment for } \\
\text { future use? }\end{array}$ & $90 \%$ & $91 \%$ & $P=0.906$ \\
\hline
\end{tabular}

\section{Applying the theory of internal control in an unstructured real world}

The statements in Table 2 tested the students' perceptions regarding the usefulness of the assignment in conceptualising auditing theory, more specifically internal controls and their impact on the real world. The vast majority of students felt that the assignment assisted them to conceptualise auditing theory and allowed them to gain insight into internal controls. Students perceived that they were able to identify internal control weaknesses in the world around them with relative ease. Notably, the perceived increase in awareness of the importance of internal controls; awareness that controls exist in the real world; and awareness that weaknesses in controls have an influence on businesses, was significant. The means were above 4 , tending towards the 5 (definitely) end of the Likert scale. Students felt that they were engaged in the learning process and were encouraged to apply their theoretical knowledge to new and unique situations. These findings are consistent with those of previous studies indicating that where case studies or roleplays simulate the real world in learning interventions, students gained the required competencies (Steenkamp and Rudman 2007, 35; Steenkamp and Von Wielligh 2011, 17; Rudman and Terblanche 2011, 68; Stainbank 2005, 134). This specific assignment deepened the learning, as it was not limited to a single context. There were significant differences in the responses of the two groups relating to their perceived insight into the practical operations of internal control and the amount of discussion on the topic. In both cases the 2015 cohort perceived a higher degree of agreement. This may have been due to the fact that there examples from 2014 were available to guide them.

Students' general comments were that the assignment made auditing more "real" for them and it helped them see that internal controls are relevant and present all around them.

Table 2: Perceptions of the \#auditsexy assignment in relation to conceptualising auditing in the real world

Questions in the form of a Likert scale of agreement ranging from 1 being (not at all) to 5 (definitely).

\begin{tabular}{|c|c|c|c|c|}
\hline & Statement & $\begin{array}{c}\text { Combined } \\
\text { Mean }\end{array}$ & $\begin{array}{l}\text { Standard } \\
\text { Deviation }\end{array}$ & $\begin{array}{l}\text { Pearson Chi- } \\
\text { square between } \\
2014 \text { and } 2015\end{array}$ \\
\hline \multicolumn{5}{|c|}{ Conceptualise auditing and participate in the learning process } \\
\hline 2.1 & $\begin{array}{l}\text { The assignment benefited your ability to } \\
\text { conceptualise auditing. }\end{array}$ & 3.6 & 0.976 & $P=0.309$ \\
\hline 2.2 & $\begin{array}{l}\text { You were an active participant in the learning } \\
\text { process. }\end{array}$ & 3.9 & 0.852 & $P=0.196$ \\
\hline 2.3 & The assignment encouraged you to apply & 3.9 & 0.858 & $P=0.427$ \\
\hline
\end{tabular}




\begin{tabular}{|c|c|c|c|c|}
\hline & Statement & $\begin{array}{c}\text { Combined } \\
\text { Mean }\end{array}$ & $\begin{array}{l}\text { Standard } \\
\text { Deviation }\end{array}$ & $\begin{array}{l}\text { Pearson Chi- } \\
\text { square between } \\
2014 \text { and } 2015\end{array}$ \\
\hline \multicolumn{5}{|c|}{ Conceptualise auditing and participate in the learning process } \\
\hline & $\begin{array}{l}\text { your theoretical knowledge to new and } \\
\text { unique situations. }\end{array}$ & & & \\
\hline 2.4 & $\begin{array}{l}\text { The assignment increased your insight into } \\
\text { the practical operations of internal controls. }\end{array}$ & 4.0 & 0.821 & $P=0.040$ \\
\hline 2.5 & $\begin{array}{l}\text { The assignment peeked your interest in the } \\
\text { subject and stimulated discussion of the } \\
\text { problem. }\end{array}$ & 3.8 & 0.954 & $P=0.002$ \\
\hline \multicolumn{5}{|c|}{ Real world application } \\
\hline 2.6 & $\begin{array}{l}\text { What was the level of ease with which you } \\
\text { were able to identify weaknesses in internal } \\
\text { controls? }\end{array}$ & 3.9 & 0.898 & $P=0.554$ \\
\hline 2.7 & $\begin{array}{l}\text { What degree of awareness do you have of } \\
\text { the impact of internal controls as part of any } \\
\text { business or organisation and their } \\
\text { importance? }\end{array}$ & 4.1 & 0.856 & $P=0.118$ \\
\hline 2.7 & $\begin{array}{l}\text { To what extent did you realise that internal } \\
\text { controls exist in the real world? }\end{array}$ & 4.3 & 0.780 & $P=0.164$ \\
\hline 2.9 & $\begin{array}{l}\text { To what extent do you have an increased } \\
\text { awareness of internal controls and internal } \\
\text { controls weaknesses in the real world? }\end{array}$ & 4.2 & 0.919 & $P=0.097$ \\
\hline
\end{tabular}

\section{Game-like influences and lecturer participation in the assignment}

The statements in Table 3 tested the students' perceptions of the game-like elements of the assignment. The 2014 cohort showed more interest in the sponsored prize than the 2015 cohort. However more than half of all the students found it interesting. Students found the added element of introductory clips, lecturer-made video adverts and the awards ceremony interesting. The students placed a high value on lecturer participation in the assignment, which was perceived to influence their learning experience.

Students' general comments were that they enjoyed the "fun" elements that the lecturers built into the assignment and were thankful for lecturer participation.

Table 3: Perceptions of the game-like influences and lecturer involvement in the assignment

Questions in the form of Yes (agree) or No (disagree)

\begin{tabular}{|c|c|c|c|c|}
\hline \multirow{2}{*}{\multicolumn{2}{|c|}{ Question }} & \multicolumn{2}{|c|}{$\begin{array}{c}\text { Percentage of } \\
\text { students who agreed }\end{array}$} & \multirow{2}{*}{$\begin{array}{l}\text { Pearson Chi- } \\
\text { square between } \\
2014 \text { and } 2015\end{array}$} \\
\hline & & 2014 & 2015 & \\
\hline 3.1 & $\begin{array}{l}\text { Did the link to a prize make the assignment more } \\
\text { interesting? }\end{array}$ & $68 \%$ & $54 \%$ & \\
\hline 3.2 & $\begin{array}{l}\text { Did the link to fun activities - intro clips, video } \\
\text { adverts, and awards) make it more interesting? }\end{array}$ & $90 \%$ & $87 \%$ & $P=0.640$ \\
\hline 3.3 & $\begin{array}{l}\text { Did lecturer participation influence the learning } \\
\text { experience? }\end{array}$ & $80 \%$ & $90 \%$ & $P=0.088$ \\
\hline 3.4 & Is lecturer participation in assignments important? & $95 \%$ & $95 \%$ & $P=0.928$ \\
\hline
\end{tabular}




\section{Did the \#auditsexy assignment create an opportunity for the student to practice} and refine specific pervasive skills required by the profession?

The statements in Table 4 tested students' broad perceptions of whether the assignment allowed them to learn non-academic skills and think of broader commercial, legislative and confidentiality issues. This is followed by detailed statements in Tables 5-7 which present their perceptions of specific pervasive skills and qualities that accounting students have to master. The relevant pervasive skills and qualities set out in the Competency Framework were used to present the students' perceptions (Tables 5-7) of the opportunities in the assignment to practice those skills.

\section{Broad perceptions of the assignment's application to non-academic skills}

Table 4 shows that more than two thirds of the students agreed that they learned non-academic skills from the assignment. The majority agreed that the assignment allowed them to think about not only the auditing theory, but also more broadly about business, the businesses included in their post, their own conduct, social issues, and confidentiality issues. It allowed them to be creative. These broad perceptions indicate that the students were able to practice skills not traditionally taught in the classroom. This confirms that using an unstructured assignment in this manner also facilitates the use of pervasive skills as was previously found when using structured case studies or role plays (Steenkamp and Von Wielligh 2011, 10; Rudman and Terblanche 2011, 68; Steenkamp and Rudman 2007, 35; Stainbank 2005, 134). The 2015 cohort rated their consideration of broader business issues and legislative issues significantly higher than the 2014 cohort did. This may be due to the increased focus in the initial presentation of the assignment. The initial discussion included lessons from 2014 as risks of which students should be aware.

Table 4: Broad perceptions of the assignments' application to non-academic skills

Questions in the form of Yes (agree) or No (disagree)

\begin{tabular}{|c|l|c|c|c|}
\hline \multicolumn{2}{|c|}{ Question } & \multicolumn{2}{c|}{$\begin{array}{c}\text { Percentage students } \\
\text { who agreed }\end{array}$} & $\begin{array}{c}\text { Pearson Chi- } \\
\text { square between } \\
\text { 2014 and 2015 }\end{array}$ \\
\cline { 3 - 4 } & \multicolumn{2}{|c|}{$\mathbf{2 0 1 4}$} & $\mathbf{2 0 1 5}$ & $\mathrm{P}=0.12$ \\
\hline 4.1 & $\begin{array}{l}\text { Did the assignment allow you to learn non-academic } \\
\text { skills? }\end{array}$ & $68 \%$ & $79 \%$ & $\mathrm{P}=0.423$ \\
\hline 4.2 & $\begin{array}{l}\text { Did the assignment allow you to consider your impact } \\
\text { on the community and the outside world? }\end{array}$ & $83 \%$ & $77 \%$ & $\mathrm{P}=0.588$ \\
\hline 4.3 & $\begin{array}{l}\text { Did you consider the brand of the company in your } \\
\text { post? }\end{array}$ & $83 \%$ & $86 \%$ & $\mathrm{P}=0.244$ \\
\hline 4.4 & Did you consider the impact on the sponsors? & $81 \%$ & $88 \%$ & $\mathrm{P}=0.001$ \\
\hline 4.5 & $\begin{array}{l}\text { Did the assignment allow you to think about broader } \\
\text { business issues? }\end{array}$ & $71 \%$ & $91 \%$ & $\mathrm{P}=0.707$ \\
\hline 4.6 & $\begin{array}{l}\text { Did you consider professional conduct and use } \\
\text { professional judgement? }\end{array}$ & $85 \%$ & $87 \%$ & $\mathrm{P}=0.154$ \\
\hline 4.7 & Did you think about confidentiality issues? & $80 \%$ & $89 \%$ & \\
\hline
\end{tabular}




\begin{tabular}{|c|l|c|c|c|}
\hline \multicolumn{2}{|c|}{ Question } & \multicolumn{2}{c|}{$\begin{array}{c}\text { Percentage students } \\
\text { who agreed }\end{array}$} & $\begin{array}{c}\text { Pearson Chi- } \\
\text { square between } \\
\mathbf{2 0 1 4} \text { and 2015 }\end{array}$ \\
\cline { 3 - 4 } & $\mathbf{2 0 1 4}$ & $\mathbf{2 0 1 5}$ & $\mathrm{P}=0.008$ \\
\hline 4.8 & Did you think about broader legislative issues? & $76 \%$ & $93 \%$ & $\mathrm{P}=0.396$ \\
\hline 4.9 & Did you think about social issues? & $71 \%$ & $78 \%$ & \\
\hline
\end{tabular}

Source: Created by author

\section{Ethical behaviour and professionalism (SAICA 2010)}

Table 5 shows the students' perceptions of their own ethical behaviour and professionalism during the assignment. The timing of the assignment aligned with the lecturing of ethics and consequently presented a great opportunity to apply ethics frameworks to a "real-time"/"realworld" situation. Students felt that the assignment allowed them to apply their own ethics reasoning process and to consider the impact of their behaviour on public interest, with a mean of well above 3.5 leaning towards the 5 (definitely) end of the Likert scale. Since the assignment was on social media, the students had the perception (means close to 4 ) that it enabled them to consider the protection of confidential information, presenting information fairly and the impact of their behaviour on the chartered accountancy profession.

Table 5: Perceptions of students regarding what they learned about ethical behaviour and professionalism (SAICA 2010)

Statements in the form of a Likert scale of agreement ranging from 1 (not at all) to 5 (definitely).

\begin{tabular}{|c|c|c|c|c|}
\hline & Statement & $\begin{array}{c}\text { Combined } \\
\text { Mean }\end{array}$ & $\begin{array}{l}\text { Standard } \\
\text { Deviation }\end{array}$ & $\begin{array}{l}\text { Pearson Chi- } \\
\text { square between } \\
2014 \text { and } 2015\end{array}$ \\
\hline \multicolumn{5}{|c|}{ Ethical reasoning process and protection of public interest } \\
\hline 5.1 & $\begin{array}{l}\text { Your ability to use an ethical reasoning process to } \\
\text { determine appropriate behaviour. }\end{array}$ & 3.8 & $P=0.375$ & 0.864 \\
\hline 5.2 & $\begin{array}{l}\text { Your ability to consider and apply your own } \\
\text { decision making with its impact on public interest } \\
\text { and appropriate behaviour. }\end{array}$ & 3.8 & $P=0.623$ & 0.825 \\
\hline \multicolumn{5}{|c|}{ Performs work competently and with due care } \\
\hline 5.3 & $\begin{array}{l}\text { Your ability to present the set of facts and } \\
\text { circumstances identified fairly relating to the } \\
\text { weakness in internal control. }\end{array}$ & 3.9 & $\mathrm{P}=0.469$ & 0.829 \\
\hline \multicolumn{5}{|c|}{ Protects confidentiality of information } \\
\hline 5.4 & Your ability to protect confidential information. & 3.9 & $P=0.091$ & 0.836 \\
\hline \multicolumn{5}{|c|}{ Maintains and enhances the professions reputation } \\
\hline 5.5 & $\begin{array}{l}\text { Your impact on the reputation of the chartered } \\
\text { accountancy profession. }\end{array}$ & 3.9 & $P=0.007$ & 0.869 \\
\hline
\end{tabular}

Source: Created by author

\section{Personal attributes (SAICA 2010)}

Table 6 shows the students' perceptions regarding their application of the personal attribute of being innovative as required in the Competency Framework. With a mean of around 3.75, the perception was that students were able to be innovative and think outside the box in the unstructured setting. This shows that taking the assignment out of the classroom into the real world allowed students to engage actively with the real-wold applications of internal control 
theory as recommended by Adams Becker et al. $(2017,6)$.

Table 6: Perceptions of students regarding their lessons relating to the personal attributes (SAICA 2010)

Statements in the form of a Likert scale of agreement ranging from 1 (not at all) to 5 (definitely).

\begin{tabular}{|c|c|c|c|c|}
\hline & Statement & $\begin{array}{c}\text { Combined } \\
\text { Mean }\end{array}$ & $\begin{array}{l}\text { Standard } \\
\text { Deviation }\end{array}$ & $\begin{array}{l}\text { Pearson Chi- } \\
\text { square between } \\
2014 \text { and } 2015 \\
\end{array}$ \\
\hline InnoI & tion & & & \\
\hline 6.1 & $\begin{array}{l}\text { Your ability to think innovatively in an } \\
\text { unstructured auditing situation to find a solution } \\
\text { to present the control weakness identified. }\end{array}$ & 3.9 & $P=0.220$ & 0.889 \\
\hline 6.2 & $\begin{array}{l}\text { Your ability to think conceptually? In other } \\
\text { words your ability to "think outside the box". }\end{array}$ & 3.8 & $P=0.098$ & 0.955 \\
\hline
\end{tabular}

Source: Created by author

\section{Professional skills (SAICA 2010)}

Table 7 shows that students felt that the assignment allowed them to integrate the class taught theory of auditing to assessments, as well as across auditing topics, including ethics and internal controls. The assignment allowed them to critically evaluate, synthesise and analyse information to present in their video or photo and to create the most appropriate response (by providing a recommendation to correct the weakness identified in 2015). With means well above 3.7 closer to 5 (definitely), the perception was that the assignment created a safe space to practice these professional skills.

Table 7: Perceptions of students regarding what they learned about professional skills (SAICA 2010)

Statements in the form of a Likert scale of agreement ranging from 1 (not at all) to 5 (definitely)

\begin{tabular}{|c|c|c|c|c|}
\hline \multicolumn{2}{|r|}{ Statement } & $\begin{array}{c}\text { Combined } \\
\text { Mean }\end{array}$ & $\begin{array}{l}\text { Standard } \\
\text { Deviation }\end{array}$ & $\begin{array}{l}\text { Pearson Chi- } \\
\text { square between } \\
2014 \text { and } 2015\end{array}$ \\
\hline \multicolumn{5}{|c|}{ Integrated thinking } \\
\hline 7.1 & $\begin{array}{l}\text { The ability to integrate your understanding of the } \\
\text { different components of auditing courses. }\end{array}$ & 3.9 & $P=0.200$ & 0.881 \\
\hline 7.2 & $\begin{array}{l}\text { The ability to visualise the internal control } \\
\text { process when doing a question. }\end{array}$ & 3.9 & $P=0.425$ & 0.929 \\
\hline \multicolumn{5}{|c|}{ Evaluates information and ideas } \\
\hline 7.3 & $\begin{array}{l}\text { Your ability to think critically about issues and to } \\
\text { evaluate the idea surrounding your presentation } \\
\text { of the control weakness identified. }\end{array}$ & 3.8 & $P=0.542$ & 0.827 \\
\hline 7.4 & Your analytical skills. & 3.7 & $P=0.005$ & 0.923 \\
\hline 7.5 & $\begin{array}{l}\text { The ability to consider problems and evaluate a } \\
\text { situation from more than one perspective. }\end{array}$ & 3.9 & $P=0.028$ & 0.840 \\
\hline 7.6 & $\begin{array}{l}\text { Your ability to synthesize (combine) the essential } \\
\text { elements of a given situation. }\end{array}$ & 3.7 & $P=0.044$ & 0.819 \\
\hline \multicolumn{5}{|c|}{ Draws conclusions/form opinions } \\
\hline 7.7 & Your ability to identify problems immediately. & 3.8 & $P=0.236$ & 0.797 \\
\hline
\end{tabular}




\section{What were the accounting students' perceptions of using Facebook as the platform for the \#auditsexy assignment and did it have an impact on their learning experience?}

Table 8 considers the students perceptions of Facebook as the choice of platform for the assignment. More than 80 per cent of the students preferred the use of Facebook over the normal institutional platform. The majority of students felt that the use of Facebook created a collaborative learning space. However, the 2014 cohort held this opinion more than their 2015 counterparts. There was significant variance. Students stated that they learned from each other outside of the classroom through posts and comments on Facebook. This finding is consistent with the findings of Menzies et al. $(2017,41)$ and Petrović et al. $(2012,357)$. They also enjoyed the fact that they could see each other's posts. Most of the students in the 2015 cohort did not feel that they participated more in the assignment by liking and sharing posts on Facebook, but two thirds of the 2014 cohort indicated that the use of Facebook enhanced their participation. It is noteworthy that the group on Facebook was a closed and not a public group in the latter year. The use of Facebook for this assignment was not really perceived to improve student relationships. It was however, about half of the students perceived it to increase the overall interaction among them. It is interesting to observe that less than half of the students in 2014 thought that an element of privacy was lost with the use of Facebook, compared with 60 per cent in 2015. This is despite the fact that the Facebook group was closed and limited to members of the closed group who had been approved by the lecturers. Despite the findings of Bosch (2009, 195-196), less than half of the students were of the opinion that the line between their university lives and their private lives had been transgressed.

Table 8: Perceptions of students regarding the use of Facebook as a tool for learning interventions Questions in the form of Yes (agree) or No (disagree)

\begin{tabular}{|c|c|c|c|c|}
\hline \multirow{2}{*}{\multicolumn{2}{|c|}{ Question }} & \multicolumn{2}{|c|}{$\begin{array}{l}\text { Percentage students } \\
\text { who agreed }\end{array}$} & \multirow{2}{*}{$\begin{array}{l}\text { Pearson Chi-square } \\
\text { between } 2014 \text { and } \\
2015\end{array}$} \\
\hline & & 2014 & 2015 & \\
\hline \multicolumn{4}{|c|}{ Use of Facebook compared with other institutional platforms } & \\
\hline 8.1 & $\begin{array}{l}\text { Did you enjoy the use of Facebook over the } \\
\text { normal institutional platform? }\end{array}$ & $88 \%$ & $82 \%$ & $P=0.355$ \\
\hline \multicolumn{4}{|c|}{ Collaborative learning space } & \\
\hline 8.2 & $\begin{array}{l}\text { Does the use of Facebook create a } \\
\text { collaborative learning space? }\end{array}$ & $85 \%$ & $69 \%$ & $\mathrm{P}=0.040$ \\
\hline 8.3 & $\begin{array}{l}\text { Did you learn from other students on the } \\
\text { Facebook page? }\end{array}$ & $61 \%$ & $62 \%$ & $\mathrm{P}=0.896$ \\
\hline 8.4 & $\begin{array}{l}\text { Did you learn from other students' posts on } \\
\text { Facebook? }\end{array}$ & $63 \%$ & $70 \%$ & $P=0.425$ \\
\hline 8.5 & $\begin{array}{l}\text { Did the \#auditsexy assignment increase the } \\
\text { amount of time you used to discuss auditing } \\
\text { (and the \#auditsexy assignment) with friends } \\
\text { outside of lecturers? }\end{array}$ & $80 \%$ & $73 \%$ & $P=0.302$ \\
\hline 8.6 & Did you enjoy the interaction with friends on & $88 \%$ & $82 \%$ & $P=0.355$ \\
\hline
\end{tabular}




\begin{tabular}{|c|c|c|c|c|}
\hline \multirow{2}{*}{\multicolumn{2}{|c|}{ Question }} & \multicolumn{2}{|c|}{$\begin{array}{c}\text { Percentage students } \\
\text { who agreed }\end{array}$} & \multirow{2}{*}{$\begin{array}{l}\text { Pearson Chi-square } \\
\text { between } 2014 \text { and } \\
2015\end{array}$} \\
\hline & & 2014 & 2015 & \\
\hline & the assignment? & & & \\
\hline 8.7 & $\begin{array}{l}\text { Did you participate more as it was on } \\
\text { Facebook (due to liking and sharing posts)? }\end{array}$ & $66 \%$ & $45 \%$ & $P=0.018$ \\
\hline 8.8 & $\begin{array}{l}\text { Did you like seeing other students' feedback } \\
\text { to what you posted on the Facebook page? }\end{array}$ & $78 \%$ & $72 \%$ & $P=0.429$ \\
\hline 8.9 & $\begin{array}{l}\text { Did using Facebook help you interact with } \\
\text { more students? }\end{array}$ & $59 \%$ & $52 \%$ & $P=0.432$ \\
\hline 8.10 & $\begin{array}{l}\text { Did the assignment improve relationships with } \\
\text { other students? }\end{array}$ & $27 \%$ & $33 \%$ & $P=0.384$ \\
\hline \multicolumn{5}{|c|}{ Future uses for Facebook } \\
\hline 8.11 & $\begin{array}{l}\text { Would you recommend using Facebook in } \\
\text { future assignments? }\end{array}$ & $73 \%$ & $66 \%$ & $P=0.384$ \\
\hline 8.12 & $\begin{array}{l}\text { Would you recommend using Facebook in } \\
\text { lectures? }\end{array}$ & $61 \%$ & $57 \%$ & $P=0.636$ \\
\hline 8.13 & $\begin{array}{l}\text { Would you use social media (i.e. Facebook) to } \\
\text { discuss topics with peers and lecturers? }\end{array}$ & $51 \%$ & $58 \%$ & $P=0.302$ \\
\hline \multicolumn{5}{|c|}{ Privacy } \\
\hline 8.14 & $\begin{array}{l}\text { Did the use of Facebook make you lose an } \\
\text { element of privacy? }\end{array}$ & $41 \%$ & $60 \%$ & $\mathrm{P}=0.425$ \\
\hline 8.15 & $\begin{array}{l}\text { Did you feel that the line between studies and } \\
\text { personal life was infringed upon by using } \\
\text { Facebook? }\end{array}$ & $37 \%$ & $43 \%$ & $\mathrm{P}=0.495$ \\
\hline
\end{tabular}

Source: Created by author

\section{What additional lessons did the students learn regarding the risks of social media to themselves, the university or to the businesses used in their Facebook posts?}

The statements in Table 9 tested the students' perceptions regarding their exposure to social media risks while using Facebook. The students had very positive perceptions of their awareness and consideration of the risks that became apparent during the assignment. They felt that they would consider the consequences of their own actions and behaviour on their reputation in future. It also alerted students to privacy issues relating to social media. When asked to identify in a narrative to show which social media risks they had been made aware of, it included copyright infringements, disclaimers, personal and corporate reputational risk, reputation risk for the university or sponsor, the impact of sensitive information online and the risk of showing others how to commit a crime. An incidental observation regarding the students posting on Facebook was that the majority indicated that they used the post to identify a valid internal control. However, some intended to be humorous, and a small number intended to shock viewers. This creates a consideration for faculty should they wish to use the platform in future. They should ensure that the content posted is controlled as was the case in the 2015 closed Facebook group. 
Table 9: Perceptions of students regarding the use of Facebook as a tool for learning interventions Questions in the form of Yes (agree) or No (disagree).

\begin{tabular}{|c|c|c|c|c|}
\hline \multirow{2}{*}{\multicolumn{2}{|c|}{ Question }} & \multicolumn{2}{|c|}{$\begin{array}{c}\text { Percentage students who } \\
\text { agreed }\end{array}$} & \multirow{3}{*}{$\begin{array}{c}\text { Pearson Chi- } \\
\text { square between } \\
\mathbf{2 0 1 4} \text { and } 2015 \\
P=0.053\end{array}$} \\
\hline & & 2014 & 2015 & \\
\hline 9.1 & $\begin{array}{l}\text { Did the assignment allow you to consider ethical } \\
\text { issues of posting items online? }\end{array}$ & $83 \%$ & $93 \%$ & \\
\hline 9.2 & $\begin{array}{l}\text { Did the assignment allow you to think about your } \\
\text { reputation in future? }\end{array}$ & $85 \%$ & $94 \%$ & $P=0.063$ \\
\hline 9.3 & Did you think about privacy issues? & $88 \%$ & $91 \%$ & $P=0.469$ \\
\hline 9.4 & $\begin{array}{l}\text { Did you think about the consequences of your } \\
\text { actions? }\end{array}$ & $88 \%$ & $93 \%$ & $P=0.301$ \\
\hline 9.5 & $\begin{array}{l}\text { Did the use of the \#auditsexy minute make you } \\
\text { reconsider your own social media behaviour? }\end{array}$ & $76 \%$ & $86 \%$ & $P=0.098$ \\
\hline
\end{tabular}

Source: Created by author

\section{CONCLUSION}

The objective of this study was to present accounting students' perceptions of an unstructured, real-world assignment using Facebook as a tool for learning, collaboration and engagement. The student perceptions show that applying auditing principles to real-life scenarios allows students to solidify their understanding for deep learning. This finding corresponds to existing research. This assignment demonstrates that learning interventions can be unstructured and non-restrictive. One does not need not be restricted to one context or case study to achieve the same outcomes and add richness of any context to the learning. This creates opportunities within teaching to be more innovative when planning learning interventions within real world contexts and opens more communication channels for teaching. This enhances the continual dialogue between teacher, material and student through the learning process as suggested within the Conversational Framework (Laurillard 2012). It does however, limit the control that the teacher has over the learning environment and requires teachers clearly communicate the scope, timeframes and engagement commitments of both teacher and student up front. Teachers are then also required to adapt and respond to unforeseen questions and challenges raised real time to prevent confusion that may restrict learning. The nature of the assignment created the perception that students would be able to practice pervasive skills that they do not get to practice in a traditional lecture hall. The non-restrictive nature of the assignment allowed students to be more innovative than would have been possible using a single case study or role play. Students enjoyed the use of Facebook as a platform to communicate and learn from each other and educators. This confirmed the findings of Dunn $(2013,2)$ that despite the challenges teaching and learning in higher education can be enhanced by the use of social media and the 
underpinning social networking principle by increasing student engagement, collaboration and teacher and student interaction. The students found the use of Facebook useful to the assignment and most recommended it be used in future. Overall, the assignment achieved the intended outcomes of giving students an opportunity to learn and concretise audit theory in the real world, actively practicing pervasive skills and creating an awareness of social media risks. Higher education institutions are moving towards incorporating more blended learning based pedagogies across specialisation areas (Adams Becker et al. 2017, 2; Krause 2007 as cited in Bath and Bourke 2010, 1). The findings of this research support this trend in higher education and show that an effective tool that can be used in general higher education as part of these pedagogies is social media, more specifically Facebook. The cost effectiveness, familiarity, mobility, social-reach and wide use of Facebook make is an effective tool to support learning interventions that educators can use no matter the class size or the limited availability of resources. Thus, educators are encouraged to keep trying new things by using technology to keep students engaged and actively learning while carefully considering the risks it presents.

\section{REFERENCES}

Adams Becker, S. M., A. Cummins, A. Davis, C. Freeman, C. Hall Giesinger and V. Ananthanarayanan. 2017. NMC Horizon Report: 2017 Higher Education Edition. Austin, Texas: The New Media Consortium. https://learntechlib.org/p/182005/

Arens, A. A., R. G. May and G. Dominiak. 1970. A simulated case for audit education. The Accounting Review 45(3): 573-578.

Barac, K. 2009. South African training officers' perceptions of the knowledge and skills requirements of entry-level Training Accountants. Meditari Accountancy Research 17(2): 19-46. https://www.emeraldinsight.com/doi/pdfplus/10.1108/10222529200900010

Bath, D. and J. Bourke. 2010. Getting started with blended learning. Australia: Griffith Institute for Higher Education. https://www.dkit.ie/system/files/Getting\%20started\%20with\%20blended\%20 learning\%20Griffith\%20University\%20AU_0.pdf

Bosch, T. E. 2009. Using online social networking for teaching and learning: Facebook use at the University of Cape Town. Communicatio 35(2): 185-200. http://www.tandfonline.com/ doi/abs/10.1080/02500160903250648

Cilliers, E. J. 2017. The challenge of teaching Generation Z. International Journal of Social Sciences 3(1): 188-198. https://dx.doi.org/10.20319/pijss.2017.31.18819

Coetzee, S. and R. Oberholzer. 2009. The tax knowledge of South African Trainee Accountants: A survey of the perceptions of training officers in public practice. Accounting Education 18(4): 421441. https://doi.org/10.1080/09639280902719424

Crawford, L., C. Helliar and E. Monk. 2011. Generic skills in Audit education. Accounting Education: An International Journal 20(2): 115-131. https://doi.org/10.1080/09639284.2011.557487

De Villiers, R. 2010. The incorporation of soft skills into Accounting curricula: Preparing Accounting graduates for their unpredictable futures. Meditari Accountancy Research 18(2): 1-22. https://www.emeraldinsight.com/doi/pdfplus/10.1108/10222529201000007 
De Villiers, R. R. 2015. Emphasising the usefulness of simulations in Audit education: Student perceptions at a SAICA-accredited South African university. Journal of Economic and Financial Sciences (JEF) July 2016: 485-502. http://journals.co.za/docserver/fulltext/jefs/9/2/jefs_v9_n2 a10.pdf?expires $=1530090345 \& \mathrm{id}=\mathrm{id} \&$ accname $=$ guest $\&$ checksum $=$ ECD62CBDB3827D19F63 F3431FC41B71B

Dolmans, D. H. J. M. and S. M. M. Loyens, H. Marcg and D. Gijbels. 2016. Deep and surface learning in problem-based learning: A review of the literature. Adv in Health Sci Educ 21: 1087-1112. https://doi.org/10.1007/s10459-015-9645-6

Dunn, L. 2013. Teaching in higher education: Can social media enhance the learning experience? In 6 th Annual University of Glasgow Learning and Teaching Conference, 19th Apr 2013. Glasgow, UK. http://eprints.gla.ac.uk/78491/1/78491.pdf

Fletcher, M. 2015. Professional learning. In Professional learning in higher education and communities: Towards a new vision for action research, ed. O. Zuber-Skerritt and J.Kearney, 41-75. London: Palgrave Macmillan.

Gezgin, D. M., M. Adnan and M. Acar Guvendir. 2018. Mobile learning according to students of Computer Engineering and Computer Education: A comparison of attitudes. Turkish Online Journal of Distance Education 19(1): 4-17. https://files.eric.ed.gov/fulltext/EJ1165892.pdf

Hall, M., A. Ramsay and J. Raven. 2004. Changing the learning environment to promote deep learning approaches in first-year Accounting students. Accounting Education 13(4): 489-505. https://doi.org/10.1080/0963928042000306837

Hiralaal, A. 2012. Students' experiences of blended learning in Accounting education at the Durban University of Technology. South African Journal of Higher Education 26(2): 316-328. http://journals.co.za/docserver/fulltext/high/26/2/high_v26_n2_a9.pdf?expires=1530090517\&id $=\mathrm{id} \&$ accname $=57845 \&$ checksum $=\mathrm{C} 532 \mathrm{~B} 8045 \mathrm{C} 946 \mathrm{~A} 14217 \mathrm{BAF} 83 \mathrm{~B} 889 \mathrm{~F} 12 \mathrm{C}$

Jones, V., J. Jo and P. Martin. 2007. Future schools and how technology can be used to support Millennial and Generation-Z students. ICUT (Proceedings B): 886-891. https://researchrepository.griffith.edu.au/handle/10072/19022

Helliar, C. V., E. A. Monk and L. A. Stevenson. 2009. The development of Trainee Auditors' skills in tertiary education. International Journal of Auditing 13(3): 185-202. https://doi.org/10.1111/ j.1099-1123.2009.00385.x

Keevy, M. 2016. Using case studies to transfer soft skills (Also known as pervasive skills): Empirical evidence. Meditari Accountancy Research 24(3): 458-474. https://www.emeraldinsight.com/ doi/full/10.1108/MEDAR-04-2

Kolb, D. A. 1984. The experiential learning: Experience as the source of learning and development. New Jersey: Prentice Hall.

Kruger, S. 2011. Students' and lecturers' perceptions of the effect of open-book examinations on the learning behaviour of accountancy students. South African Journal of Accounting Research 25(1): 35-57. https://doi.org/10.1080/10291954.2011.11435152

Laurillard, D. 2012. Teaching as a design science: Building Pedagogical Patterns for learning and technology. London: Routledge.

Menzies, R., K. Petrie and M. Zarb. 2017. A case study of Facebook use: Outlining a multi-layer strategy for higher education. Education and Information Technologies 22(1): 39-53. https://link. springer.com/article/10.1007/s10639-015-9436-y

Petrović, N., D. Petrović and V. Jeremić. 2012. Possible educational use of Facebook in higher environmental education. International Conference on Information Communication Technologies (ICICTE): 355-362. http://www.icicte.org/Proceedings2012/Papers/09-1-Petrovic.pdf 
Prince, M. 2004. Does active learning work? A review of the research. Journal of Engineering Education July 2004: 223-231. https://doi.org/10.1002/j.2168-9830.2004.tb00809.x

Rothman, D. 2016. A tsunami of learners called Generation Z. http://www.mdle.net/ Journal/A_Tsunami_of_Learners_Called_Generation_Z.pdf

Rudman, R. J. and J. Terblanche. 2011. Practical role-play as an extension to theoretical Audit education: A conceptualising aid. Southern African Journal of Accountability and Auditing Research 11: 63-74. https://journals.co.za/content/sajaar/11/1/EJC93868

SAICA, see South African Institute of Chartered Accountants.

South African Institute of Chartered Accountants. 2010. Competency framework: Competencies of a Chartered Accountant (SA) at entry-point of the profession. Johannesburg: SAICA.

Stainbank, L. J. 2005. Students' perceptions of the usefulness of an annual report project for the development of skills and knowledge. Meditari Accountancy Research 13(2): 129-144. https://doi.org/10.1108/10222529200500016

Steenkamp, L. P. and R. J. Rudman. 2013. Incorporating online tools in tertiary education. Contemporary Issues in Education Research (Online) 6(4): 365-372. https://scholar.sun.ac.za/ bitstream/handle/10019.1/85447/steenkamp_incorporating_2013.pdf?sequence=1

Steenkamp, L. P. and R. J. Rudman. 2007. South African students' perceptions of the usefulness of an audit simulation. Meditari Accountancy Research 15(2): 23-41. https://journals.co.za/ content/meditari/15/2/EJC72537

Steenkamp, L. P. and S. P. J. von Wielligh. 2011. The perceptions of Trainee Accountants of the usefulness of an audit simulation at university level. Southern African Journal of Accountability and Auditing Research 11(January 1986): 9-21. https://journals.co.za/content/sajaar/11/1/ EJC93872

Wessels, P. L. and L. P. Steenkamp. 2009. Generation Y students: Appropriate learning styles and teaching approaches in the economic and management sciences faculty. South African Journal of Higher Education 23(5): 1039-1058. https://journals.co.za/content/high/23/5/EJC37559 